\title{
Can Bank Mergers and Acquisitions Favour the Credit Availability for Tunisian Firms?
}

\author{
Hakimi Abdelaziz ${ }^{1} \&$ Khazri Bilel $^{1}$ \\ ${ }^{1}$ Faculty of Law, Economics and Management of Jendouba, Tunisia \\ Correspondence: Hakimi Abdelaziz, Faculty of Law, Economics and Management of Jendouba, Essanabel post \\ office BP N 554 8122, Jendouba, Tunisia. Tel: 216-97-089-263. E-mail: abdelazizhakimi@yahoo.fr
}

\author{
Received: April 26, 2012 \\ Accepted: July 16, $2012 \quad$ Published: August 1, 2012 \\ doi:10.5539/ijbm.v7n15p61 \\ URL: http://dx.doi.org/10.5539/ijbm.v7n15p61
}

\begin{abstract}
Despite of the low size of banking Merger and acquisition (M\&A) in Tunisia, we took the initiative to treat a subject which remains of topicality especially for the Tunisian context. We can consider this study like the first to be conducted in Tunisia. The aim of this paper is to empirically analyze the effect of Tunisian bank acquisition on the credit availability. On the basis of the data relating to 83 Tunisian companies in relation to the acquired bank (Banque de Sud according to the old denomination and Attijari Bank after acquisition) observed during the period 2001-2008 and in using the panel data technique, the results show that banking acquisition affects negatively and significantly the credit availability. Contrary to the literature based on this topic, the firm size is positively and significantly correlated with the credit availability whereas the effect of the bank size is no significant.
\end{abstract}

Keywords: merger and acquisation, credit availability, Tunisian firms, panel data

\section{Introduction}

During the 1990's, the financial environment knew an increasing rise of the operations of consolidation which included the banking sector. The literature founded on this topic was very abundant. We can note (Berger, Demsetz and Strahan, 1999), (Avery and Katherine, 2004), (Bonaccorsi di Patti, Emilia and Giorgio, 2007), (Francis, Iftekhar and Haizhi, 2008), (Ugwunta, Ani and Ugwuanyi, 2012). The economies of scale, the critical or the optimal size, and the improvement of the financial performances appear the most important causes of those consolidations.

The M\&A contribute to the processes of consolidation and are particularly useful when the financial environment is very competitive such as during the period of intense innovation or fast internationalization.

The financial environment knew major changes impelled by the financial globalization, the stressing of banking competition, the introduction of the financial innovation into banking system and the emergence of new banking behaviours. From the year 1980, the banks started a total movement of financial liberalization of their activities which radically increase the level of competition.

As for the financial innovation which plays a major role for the activities of investment banks. The development of new products and financial services, backed up by the increasing of market integration, led to the constitution of trade lines or banking actors. The technological innovations will undoubtedly contribute to reduce the technical and geographical barriers to the integration of the banking markets.

The acceleration of the banking consolidation encourages several theorists and researchers to put the following questions: why this banking consolidation? What are the justifications or the motivations for such consolidation?

The theoretical and empirical literature founded on this topic made it possible to give an explanation for this phenomenon of banking consolidation. The justifications of this practice can be divided into three great motivations. There are of them causes related to the financial environment which is a result of an existence of a surplus capacity in the financial sector. Other justifications go up with the banking strategy itself which is directed towards the search for a better efficiency through the research of the economies of scale and the need for an enrichment of the concept of efficiency. Within the same framework of analysis, the banking consolidation can be justified by a research of a share market. Far from the motivations of a macroeconomic nature (financial 
environment and banking strategies) the banking consolidations can be justified by micro-economic motivations like the role of the leader decision and the authorities' policies, the imitation effect and the reactive strategies.

Once, we presented the motivations of the banking consolidation especially M\&A, the exploration of the consequences of such practice looks more important. In this paper we will study the effect of the banking M\&A on the credit availability for the Tunisian companies.

The debates based on the relation M\&A and credit availability made it possible to conclude three principal results. There are many studies which highlight the negative effect of the M\&A operation on the credit availability. For example we can note Montoriol-Garriga (2008), Hasan and Wang (2008), Craig and Hardee (2007), Mitchell (2006), Sapienza (2002), Shepherd et al. (1998) etc...

Other studies, did not find any relation between the banking M\&A and the credit availability. Mercieca, Schaeck and Wolfe (2009), Shepherd, Rosen and Udell (2007), Marsch, Schmieder and Aerssen (2007), Erel (2005).Whereas, fewer are the studies which found a positive relation between banking M\&A and the availability of credit. Avery and Samolyk (2004).

The absence of a consensus with regard to the effect of the banking M\&A on the credit availability to the companies especially SME, encouraged us to empirically analyze this relation in a Tunisian context.

We should clarify that M\&A studies are more treated in developed countries than developing countries. The most reason for this difference can be explained by the few number and size of M\&A in developing countries, witches are enabling to have a strong data base to test the link between bank consolidation and bank behaviour.

The articulation of this paper can be presented as follows: we will initially introduce our study. The causes and the motivations of the banking M\&A are presented in the second part. In the third part, we will present the literature relating to our topic as well as the assumptions to be tested. The empirical results of our study are in the fourth part. Finally, we conclude the whole topic.

\section{Causes and Incentives of $M \& A$}

The causes of the banking consolidation are very diverse. In the banking literature, the most motivations are; evolution of the economic environment (deregulation, financial globalization, and information technology and communication...), and motivations specific to the companies (in particular the value creation). The value creation is regarded as the principal motivation of the process of banking consolidation.

\subsection{The Evolution of Financial Environment}

The deep transformations of the financial environment, through the financial globalization and deregulation, started in the 1970's in the Anglo-Saxon countries, in the 1980's for the European countries and in 1990's in many of emergent countries (Asia, of south-east, South America, country Central and Eastern Europe, the Maghreb...), constituted a powerful catalyst of the banking consolidations on an international context. Significant financial reforms were consequently undertaken by the authorities, aiming the decentralization of the national capital markets, the liberalization of the banking activity and supporting the rise of new financial intermediaries (OPCVM, insurances life). Gradually, on an international context, the capital markets were standardized (same products, same market segments, same processes and same intervening) and inter-connected, until creating a vast world capital market.

\subsection{The Value Creation}

In theory, the banking consolidation can make it possible to create value, either by obtaining a profit in terms of market power, or by obtaining a profit in terms of efficiency.

The market power is defined as the capacity at given moment to fix the market prices. Hannan (1991), shepherd and alii, (1999) confirm that, the prices are positively correlated with the local market shares. A power market profit can be obtained by the bringing together of two concurrent institutions on a local market. Following a M\&A operation, the size reached, can lead to an acquisation of a dominant market share, which makes it possible for the bank to influence the price level of this market and thereafter the credit policy. With the size obtained, banks can reduce costs of refinancing. Moreover, the appearance of information technologies and communication induced by new channels of distribution such as e-banking, contributes to eliminate the geographical barriers.

The banking consolidation can also allow the search for a better efficiency, the efficiency profits are carried out via the team's reorganization (leaders and employee) and/or the generalization of the best practices. These profits are obtained by the adjustment of the quantities of inputs and outputs in order to reduce the costs, to 
increase the incomes and/or to reduce the risks in order to increase the added value. We speak then "about X-efficiency" (Leibenstein, 1966).

The incentive of search for a better efficiency is induced generally by the realization of the efficiency profits by the reduction of the costs (synergy of costs), the increase in incomes (synergy of income) and exchanges the better practices between the merged banks.

Synergies of costs are carried out through a better combination of the factors of production. The objective is to benefit from the complementarities of the economies of scale, (integration of the data-processing platforms, the pooling of the back-offices...)

Synergies of incomes also result from an optimal combination of the factors of production and from a better organization of the activities. Synergies of incomes are more difficult to achieve than those of the costs, because they do not depend only on the intern's bank organization, but also, they depend on the customer's behavior. Consequently, the banking reorganizations are justified by synergies of costs rather than by synergies of incomes. For the achievement of this objective, two types of strategies, not exclusive, can be distinguished.

Initially, an operation of M\&A must lead to the economies of scale, which are generally carried out for the regroupings between similar institutions, while profiting from the distribution of the fixed costs on a high volume of production. The economies of scale are drown from the low cost (measured by the size of the bank) after an increase in production. So the weak costs result from an increase in the volume activity and from the low level of fixed costs by the merger of the secondary functions such as, the marketing the staff management, and information technologies, etc. For the strategy of M\&A, the realization of these economies is possible between two firms having the same activities and the same objective which seek to have a certain competitive advantage by reducing the unit costs of production. This is possible by improving the organization of the banking production as well as the combination of the factors of production.

In the second place, a cross border M\&A makes it possible to realize savings costs (realized by the merger of banking institutions present on heterogeneous markets, but complementary), which makes it possible to diversify the range of services by optimizing synergies between merged activities. This complementarity can extend first from a geographical point of view, as it can be understood within a complementarity framework in technical terms.

The banking integration show that the economies of scale and the savings costs and the associated X-efficiency often constitutes conventional motivations based on the value creation and the realization of synergies. Lastly, beyond the only range and economies of scale, efficiency can also be improved by a greater diversification of the risks (functional and/or geographical diversification). This strategy is particularly significant for the banking institutions.

Many studies carried out in the United States and in European context, find that other non economic motivation can also explain this phenomenon: personal interest of the manager (domination), and defensive reaction.

The decision to start banking consolidations by the managers is not always for the benefit of the owner's shareholders or for the value creation for this bank. This decision can sometimes before the benefit of the managers themselves, or so that this bank can not to be acquired by other banks, what is known "defensive acquisition" (BIS, 2001). Many authors, Caprio and Al (2004) and Spong and Sullivan (2007) largely dealt with this question relating to the internal banking governance.

Behavioral finance, agency theory and other arguments refer justifying the banking M\&A. Ayadi and al (2002), show that the manager can seek other objectives than the stallholder's value creation only.

According to Zhang (1998), the assumption of confidence excess, for certain banking M\&A, explains the positive result for the target and the null or negative result for the purchaser. That is induced by the assumption of excess of confidence combined with the agency relation but the first assumption dominates the second.

\section{M\&A and Credit Availability: Literature Review and Assumptions}

The narrow dependence of SME to the banking financing explains the direct or indirect effect of banking consolidation on their activity. Several studies were founded on the relation between the banking consolidations (M\&A, Acquisition of a holding, OPA, etc.) and the decision of credit for SME. This decision depends primarily on the credit amount, its price, guarantees, etc...

The Theorical literature review as well as the empirical studies carried out, treating this field of research, can be divided into three principal schools. The first, finds a negative relation between the banking consolidation and the credit availability for SME. The second, shows a positive effect, while the third does not find any relation 
between the banking M\&A and the credit availability. In what follows, we will try to make a synthesis on the former studies treating this topic.

Indeed, the results found by the studies of the M\&A potential impact on the SME financing, vary primarily according to the M\&A type (M\&A in-market, M\&A out-off-market). For better appreciating the effects released for each type, the majority of the authors treat this effect through the introduction of a grid of analysis, allowing the classification of the various effects generated before and after the banking M\&A, according to several criteria (Distance banks-SME, bank size, organizational structure, interest conflict, evaluation criteria and information flow).

Concerning the criterion of the bank size; the studies of Shepherd and $\mathrm{Al}$ (1998), Strahan and Weston (1996) consist in comparing the credit policy with SME carried out by merged banks, with other banks which have the same size, but non-aligned in a banking consolidation process. These authors find that for the American banks, the increase in size, measured by the total assets after M\&A, has a negative impact on the credit volume allocated to SME.

Shepherd and Udell (1996), show that in the United States, $65 \%$ of the small companies are financed by the small banks with a total assets lower than 1 billion dollar, and only $12 \%$ of the total of the small companies are financed by banks whose credit exceeds 10 billion dollars. This result suggests that the great consolidated institutions can considerably reduce the amount of the credit granted by the acquired bank after the M\&A, compared with that allocated before the banking consolidation.

\section{$H 1$ the bank size has an effect on the credit availability to SME.}

Other studies, stress the importance of the company size. Patti and Gobbi (2001), on the basis of large Italian merged banks between 1993 and 1998, found that the credit volume granted to SME (debt ranging from 130000 dollars and 2,6 million dollars) decreases, and that there is not any relation between M\&A and the credit availability for the large companies (debt exceeds 2,6 million dollars).

\section{H2 After the banking M\&A, the credit is reduced if the company is of small size.}

The debates based on the relation of banking M\&A and credit availability leads to conclude three principal results. There are studies which highlight the negative effect of the banking M\&A on the credit availability. Others studies did not find any relation between M\&A and the credit availability. Whereas the studies which found a positive relation are fewer.

The theoretical and empirical literature relating to the negative relation between the banking M\&A and the availability of credit was well enriched by several works. Montoriol-Garriga (2008), on the basis of a number of M\&A in European countries led to the following result: after the banking M\&A, the credit volume is reduced to the small companies. This result was confirmed by the study of Francis, Hasan and Wang (2008) where the acquired banks started to distribute credit for SME to less significant levels. Within this same framework of analysis, and on the basis of the data relating to banking M\&A in Italy, Bonaccorsi Di Patti and Gobbi (2007) found that this consolidation has a negative impact on the credit availability to the Italian companies.

Ahrendsen, Dixon and Luo (2003) based on merger banking during the period 1994-2001, have concluded that this strategy has a negative effect on the credit availability. Thus, the banking consolidation tends to reduce the offer of credit to SME, as checked by the work of Sapienza (2002). Berger et al. (1998), confirmed the negative relation between banking M\&A and the availability of credit. They found that the merged banks reduce credit volume offer to SME. This reduction is justified by the increase in the credit offered by the not banks merged or by the new entering in the credit market.

Another synthesis of literature which treats the negative relation between the banking M\&A and the availability of credit took account of the bank size. Craig and Hardee (2007) found that the large merged banks became more rigid to distribute credit for SME. Mitchell (2006) found that it results a significant decline in the credit availability to SME after the merger of large banks.

\section{$H 3$ the banking $M \& A$ exert a negative effect on the credit availability.}

In what follows, we present the research current which is articulated around the absence of relation between banking M\&A and credit availability. Mercieca, Schaeck and Wolfe (2009), served of a history of banking M\&A in European countries did not find any relation between the banking consolidation and the credit availability. This result confirms the findings of the study of Shepherd, Rosen and Udell (2007). The absence of an effect of the banking M\&A on the credit availability, constituted the result of the study of Marsch, Schmieder and Aerssen (2007) which was carried out on a basis of data relating to German firms financed by merged banks 
during the period 1996-2002. On the basis of data relating to large American merged banks during the period 1997-2003, Erel (2005), found that there is not a significant effect M\&A and the credit availability.

\section{$H 4$ There is not any relation between banking $M \& A$ on the credit availability.}

\section{An Empirical Study of the Effect of M\&A on Credit Availability}

To analyze the effect of the M\&A on the credit availability for the Tunisian companies, we will be served of the acquisition of the "Banque de Sud" which became Attijari Bank. With strong network of a hundred agencies and 1350 collaborators, Attijari Bank ranked as the 4th bank knew an operation of acquisition of $53,54 \%$ of its capital by the consortium maroco-Spanish Attijariwafa Bank/Grupo Santander.

Attijariwafa Bank is based in Morocco and operates in 22 country: in Africa (Tunisia, Senegal and Mali) and in Europe (Belgium, France, Germany, the Netherlands, Italy and Spain) through banking subsidiary companies controlled mainly by the group and in Abu-Dhabi, Dubai, London, Riyadh, Shanghai, Mauritania and Tripoli through representative offices.

The Tunisian banking system is mostly made-up of private banks with mixed capital (70\%); nevertheless the public banks play a major role in financing the Tunisian economy. Currently; the Tunisian banking system includes 29 banks: 18 universal bank, 8 offshore banks; 2 investment banks and 1 Islamic bank (100\% Tunisian bank). Among the 29 banks, 11 of them are listed in the Tunisian Stock Exchange.

\subsection{Data, Methodology and Specification of the Model}

The number of banking M\&A still remains limited in Tunisia. Recently in 2005, Tunisia knew an experience of acquisition of the "banque de Sud" (old denomination) which became Attijari Bank. 53,54\% of its capital was acquired by Attijariwafa Bank (Morocco) and Grupo Santander (Spain).

The methodology followed in this study consists in empirically analyzing the impact of this baking acquisition on the credit availability for the Tunisian companies. With this intention, and on the basis of a data base of Tunisian companies which were in relation with the bank in question before and after the acquisition. This choice is intended for well determining the impact of this consolidation on the credit availability. In other words, we will try to show whether the credit availability is supported after the banking acquisition or it was reduced. The coefficients sign connecting these two variables will induce the final judgment of this relation.

For the period of study, it covered the period 2001-2008. We choose this period while referring to the acquisition date which is in 2005 . We can take this date as a median of the period of study, that is to say four years before that date and three years afterwards. Generally, the effect of such a strategic decision (consolidation operation) is well collected in the long term. In our study, and under the constraint of availability of the data over a longer period, we are limited only to three years after the date of consolidation. We have collected the financial statements of 170 Tunisian companies operating in various sectors. From these financial statements, we drew the quantitative variables. For the qualitative variables, we distributed a questionnaire for these companies. Only 83 companies answered our questionnaire. That is to say a rate of response of $48,82 \%$. For the others which did not answer our questionnaire, some presented an explicit refusal, whereas others declared that they were not in relation throughout the period of our study. For example, they obtained credit from the "Banque de Sud" during period 2001-2003, but they were not in relation to “Attijari Bank" over the period 2006-2008.

The econometric method used in our study is the panel data. This technique makes it possible to take the heterogeneity of our sample. The choice of this method can be justified by the possibility of modelling the individual behaviours during defined period (among firms, consumers, households etc.). The credit availability can be expressed according to the banking acquisition by the firm characteristics, the banking system characteristics and the evolution of the financial environment.

$\mathrm{CRED}=\mathrm{f}$ \{acquisation, firm characteristics, banking system characteristics, evolution of the financial environment\}

The model can be written as follow:

$$
\begin{array}{r}
\text { CRED }_{\mathrm{i}, \mathrm{t}}=\beta_{0}+\beta_{1} \text { ACQUI }_{\mathrm{i}, \mathrm{t}}+\beta_{2} \mathrm{AGE}_{\mathrm{i}, \mathrm{t}}+\beta_{3} \mathrm{TANG}_{\mathrm{i}, \mathrm{t}}+\beta_{4} \mathrm{LEVR}_{\mathrm{i}, \mathrm{t}}+\beta_{5} \mathrm{RISK}_{\mathrm{i}, \mathrm{t}}+\beta_{6} \mathrm{SIZEF}_{\mathrm{i}, \mathrm{t}}+\beta_{7} \text { SIZEB }_{\mathrm{i}, \mathrm{t}}+\beta_{8} \\
\mathrm{CNCN}_{\mathrm{i}, \mathrm{t}}+\beta_{9} \mathrm{STBL}_{\mathrm{i}, \mathrm{t}}+\beta_{10} \text { FINLIB }_{\mathrm{i}, \mathrm{t}}+\varepsilon_{\mathrm{i}, \mathrm{t}}
\end{array}
$$

(CRED) variable dependent which measures the credit availability. It is calculated by the Neperien logarithm of the banking debts received by the company $(i)$ for the period $(t)$. (ACQUI), variable dummy measuring the banking acquisition. It takes 0 before the date of acquisition and 1 afterwards. ( $A G E$ ), the age of the firm is measured by the difference between the creation date and the date of study. (TANG), variable which measures 
the weight of the tangible fixed assets in the total assets of the firm (I). (LEVR), financial leverage which measures the weight of the banking debt in the whole of the firm debts. (RISK) this variable measures the level of risk of the companies. It is calculated by the standard deviation of the growth rate of the incomes. (SIZEF, $S I Z E B$ ), size of the firm (banks) measured by the Neperien logarithm of the total assets. (CNCN), level of banking concentration. It is measured by the index of IHH. (STBL), the banking system stability. Generally, it is measured by the non- performing loans or the level of provisions. In our study, we will use the credit risk since it is mostly significant and able to destabilize the banking system. This variable is calculated by the total credit received compared to the total assets. (LIBFIN) variable dummy which measures financial liberalization. It takes 0 for the period pre-liberalization and 1 for that post-liberalization.

For problems of regression relating to variable (LIBFIN), we eliminated this variable from our estimate and our model will take the following form:

$$
\begin{aligned}
\operatorname{CRED}_{\mathrm{i}, \mathrm{t}}= & \beta_{0}+\beta_{1} \mathrm{ACQUI}_{\mathrm{i}, \mathrm{t}}+\beta_{2} \mathrm{AGE}_{\mathrm{i}, \mathrm{t}}+\beta_{3} \mathrm{TANG}_{\mathrm{i}, \mathrm{t}}+\beta_{4} \mathrm{LEVR}_{\mathrm{i}, \mathrm{t}}+\beta_{5} \mathrm{RISK}_{\mathrm{i}, \mathrm{t}}+\beta_{6} \mathrm{SIZEF}_{\mathrm{i}, \mathrm{t}}+\beta_{7} \text { SIZEB }_{\mathrm{i}, \mathrm{t}}+\beta_{8} \\
& \mathrm{CNCN}_{\mathrm{i}, \mathrm{t}}+\beta_{9} \mathrm{STBL}_{\mathrm{i}, \mathrm{t}}+\varepsilon_{\mathrm{i}, \mathrm{t}}
\end{aligned}
$$

In the following development, we will present the descriptive statistics, the level of correlation between the variables as well as the results of our study.

\subsection{Results and Interpretation}

The results of our regression show that our estimate is random effect regression. The Hausman test is no significant whereas that of Breush Pagan is significant. In more R-sq Between $(94,62 \%)$ is higher than R-sq Within $(82,35 \%)$. For more details on the descriptive statistics see table 1 .

Table 1. Descriptives statistic

\begin{tabular}{llllll}
\hline Variables & Obs & Mean & Std. Dev. & Min & Max \\
\hline Cred & 664 & 14.59223 & 1.858924 & 8.246172 & 16.9716 \\
acqui & 664 & 0.375341 & .4871774 & 0 & 1 \\
age & 664 & 22.25632 & 21.30573 & 6 & 34 \\
tang & 664 & 16.16025 & .9601071 & 12.05271 & 17.30129 \\
levr & 664 & .1088424 & .1025544 & .0002452 & .4236299 \\
risk & 664 & 1.524012 & 2.588672 & .2343702 & 9.857179 \\
sizef & 664 & 17.63064 & .4147096 & 16.54447 & 18.39292 \\
sizeb & 664 & 14.65002 & .2741284 & 14.27663 & 15.21243 \\
cncn & 664 & .7215082 & .0095795 & .709069 & .7425511 \\
stbl & 664 & .1104856 & .0019495 & .106478 & .1135766 \\
\hline
\end{tabular}

The table 2 shows the level of correlation between all the variables of our study. It should be noted that the correlation matrix indicates a weak correlation between the various variables. This confirms the absence of problem of multicolinearity.

\begin{tabular}{|c|c|c|c|c|c|c|c|c|c|c|}
\hline & cred & Acqui & age & $\operatorname{tang}$ & levr & Risk & sizef & sizeb & cnen & stbl \\
\hline Cred & 1.0000 & & & & & & & & & \\
\hline acqui & -0.1100 & 1.0000 & & & & & & & & \\
\hline Age & 0.0984 & 0.0915 & 1.0000 & & & & & & & \\
\hline $\operatorname{tang}$ & 0.2629 & -0.0657 & 0.1060 & 1.0000 & & & & & & \\
\hline levr & 0.0194 & -0.1943 & -0.1879 & -0.1342 & 1.0000 & & & & & \\
\hline risk & -0.1908 & 0.0310 & -0.3062 & 0.2459 & 0.1791 & 1.0000 & & & & \\
\hline sizef & 0.4528 & 0.2129 & -0.0181 & 0.2885 & -0.0654 & 0.0310 & 1.0000 & & & \\
\hline sizeb & 0.0666 & 0.0557 & -0.0398 & -0.0518 & 0.0379 & 0.1257 & 0.0023 & 1.0000 & & \\
\hline cnen & -0.0676 & -0.3384 & -0.0172 & 0.0106 & 0.1092 & 0.0231 & 0.0193 & -0.0045 & 1.0000 & \\
\hline stbl & -0.0202 & -0.4785 & -0.0329 & 0.1079 & 0.0215 & 0.0268 & -0.0666 & -0.1072 & -0.0492 & 1.0000 \\
\hline
\end{tabular}

Table 2. Correlation matrix 
The results of our estimate are presented in the table 3. The variables TANG, LEVR, and SIZEF are positively correlated and significantly with our dependent variable CRED. The effect of the firm AGE of and the SIZEB is positive but there remains no significant. As for the variables which exert a negative effect on the credit availability, we can quote the variable of $A C Q U I, S T B L, R I S K$ and $C N C N$. However, the effect of the two last ones remains no significant.

Table 3. Random effect regression: dependent variable (CRED)

\begin{tabular}{lllcc}
\hline Cred & Coef. & Std. Err. & $\mathrm{Z}$ & $\mathrm{P}>|\mathrm{z}|$ \\
\hline Acqui & -.2278943 & 1.032361 & -4.53 & $0.000^{* * *}$ \\
age & .0031383 & .0047439 & 0.66 & 0.508 \\
tang & .4494649 & .1105878 & 4.06 & $0.000^{* * *}$ \\
levr & .1075642 & .8121097 & 7.55 & $0.000^{* * *}$ \\
risk & -.0026595 & .0406553 & -0.07 & 0.948 \\
sizef & .0361581 & .2997498 & 8.29 & $0.000^{* * *}$ \\
sizeb & .3661902 & .3390395 & 1.08 & 0.280 \\
cncn & -.6803092 & 1.308286 & -0.52 & 0.605 \\
stbl & -.0045223 & .0013010 & -6.92 & $0.003^{* * *}$ \\
cons & -1.565129 & 9.931551 & -1.08 & 0.279 \\
\hline R-sq: within & & & 0.8235 & \\
between & & & 0.9462 & \\
overall & & & 0.8270 & \\
Number of obs. & & \multicolumn{3}{c}{} \\
\hline
\end{tabular}

Let us start by interpreting the fundamental objective of our study the "ACQUI- CRED" relation. The results show a negative and significant association. Our results make announce that the banking acquisition decreases the credit availability. The strategy of credit distribution by the acquired bank can be influenced by the purchaser's behaviour that especially has rigidity about the distribution of credit to the companies during the first years. Thus, the informational character between the bank purchaser and the customers of the target bank can influence the decision of credit distribution. This result makes it possible to accept the assumption $H 3$ the banking $M \& A$ exert a negative effect on the credit availability and to reject the assumption $H 4$ there is not any effect of the banking $M \& A$ on the credit availability.

The age of the firm exerts a positive and non significant effect on the credit availability. As the firms become older, as its reputation improves and it becomes more collected by its banker. Compared with the young company, the oldest will be privileged by the offer of credit. In the same way, the need for the funds to increase their market share or for extension decisions creates a need for financing for the firm. This need will be filled by an increase in the credit demand reciprocally more significant if it is compared with that demanded by a less old company. In the same way, face to an older company, the bank has a whole history on this firm. This history makes it possible to detect the firm solvency starting by adopting the methods of discrimination between the "good" and the "bad" enterprises. Among these methods, we can point out the credit scoring.

The fixed assets variable $(T A N G)$ is correlated positively and significantly with the credit availability. In a credit relation, the tangible fixed assets of each firm can be retained as a guarantee. More the value of fixed assets is significant, more the probability of obtaining the desired credit increases.

A financial structure marked by significant debt banking in the total liability of the firm can only inform about the strong presence of the credit bank like the most important sources of financing. This justifies the positive and significant relation between the LEVR variable and the credit availability.

Contrary to the study of Strahan and Weston (1996), the credit availability improves with the firm size. Generally, the companies of big size profit from an easy access to the credit. Although the majority of the companies of our sample is of small and medium size, our results released a positive correlation. This is justified by the incentive of those companies to increase their market share and to ensure their growth. The positive 
relation between the size and the credit availability can also be justified by the encouragement of the authorities to establish new companies on the one hand and the accompaniment the extension of the other by providing the necessary fund for their investments. This encouragement is due to several reasons. Among the principal ones, we indicate the economic growth and the employment promotion. With this result, the assumption $\mathrm{H} 2$ after the banking $M \& A$, the credit availability is reduced for the small company will be rejected.

Our regression shows that the effect of the bank size on the credit availability is positive but no significant. Consequently the assumption $H 1$ the bank size can affect the credit availability fort SME is rejected.

The level of risk affects negatively the credit availability. With a higher level of risk, the bank becomes more rigid as regards for credit agreement. This goes up with the fear of credit risk following the incapacity of a firm considered to be riskier to meet its commitment.

With regard to the banking concentration variable, our results present a negative and no significant correlation with the credit availability. More than a banking system is concentrated less than competition is strong. A less competitive banking system does not offer the possibility of an easy access to credit bank. In Tunisia, the banking concentration is justified by a low number of institutions on the market more than a low level of competition.

In our study the banking stability (STBL) exerts a negative effect on the credit availability. It should be noted that the banking stability is measured by the level of credit risk. Like the majority of the emergent countries, the Tunisian banking system suffers from a high level of the non performing loan and from a low financial intensity. Two necessary pillars able to destabilize the banking system. Another justification can confirm this relation. Facing a significant level of credit risk, the bank remains more rigid with the credit distribution.

\section{Conclusion}

The low number of banking consolidation in Tunisia made us raise the following question: Why did not Tunisia know the increasing rise of the consolidation operations like the other countries? Is it a question of size of the banking system? Is it a reserve as for the consequences of such a practice? To answer this last question, we tried to study the impact of the banking consolidation on the credit availability for the Tunisian companies. It is about the acquisition of the "Banque de Sud" by the consortium maroco-Spanish Attijariwafa Bank/Grupo Santander.

The results of our study showed that there is a negative and significant relation between banking acquisition and credit availability. This result is similar to several other studies found in an American or European context. This result can also be explained by the short period after the date of acquisition (only three years) and by the low number of the banking M\&A in Tunisia. Generally, to study such relation, it should be observed over a long term period to well determine the effect of such a practice. This is not possible for reasons of constraint of posterior years on this date.

\section{Acknowledgements}

The authors are very grateful for the useful comments of the editor Suri Lee and the anonymous reviewers, which helped to significantly improve the quality of the paper.

\section{References}

Ahrendsen, B.L., Bruce L.D., \& Bing. L. (2003). The effects of bank mergers on commercial bank agricultural lending. American Agricultural Economics Association, 2003 Annual meeting, July 27-30, 2003. Montreal, Canada.

Avery, R.B., \& Katherine, S. (2004). Bank consolidation and the provision of banking services: The case of small commercial loans. Journal of Financial Services Research, 25(2-3), 291-325. http://dx.doi.org/10.1023/B:FINA.0000020667.29802.1c

Berger A. N., \& DeYoung, R. (2001). The effects of geographic expansion on bank efficiency. Journal of Financial Service Research, 19(2-3), 163-184. http://dx.doi.org/10.1023/A:1011159405433

Berger A. N., \& Udell G. F. (2002). Small business credit availability and relationships lending: The importance of bank organizational structure. Economic Journal, 112(477), 32-53. http://dx.doi.org/10.1111/1468-0297.00682

Berger A. N., Demsetz R., \& Strahan P. E. (1999). The consolidation of the financial service industry: causes, consequences and implication for the future. Journal of Banking and Finance, 23(2-4), 135-194. http://dx.doi.org/10.1016/S0378-4266(98)00125-3

Berger, A. N., Anthony. S., Joseph M. S., \& Gregory F.U. (1998). The effects of bank mergers and acquisitions 
on small business lending. Journal of Financial Economics, 50(2), 187-229. http://dx.doi.org/10.1016/S0304-405X(98)00036-1

Berger, A. N., Richard J.R., \& Gregory F.U. (2007). Does market size structure affect competition? The case of small business lending. Journal of Banking and Finance, 31(1), 11-33. http://dx.doi.org/10.1016/j.jbankfin.2005.10.010

Bonaccorsi di Patti E., \& Gobbi, G. (2001). The changing structure of local credit markets: Are small businesses special? Journal of Banking and 2509-2237. http://dx.doi.org/10.1016/S0378-4266(01)00191-1

Bonaccorsi di Patti, Emilia, \& Giorgio, G. (2007). Winners of Losers? The effects of banking consolidation on corporate borrowers. The Journal of Finance, 62(2), 669-695.

Craig, S. G., \& Pauline, H. (2007). The impact of bank consolidation on small business credit availability. Journal of Banking and Finance, 31(4), 1237-1263. http://dx.doi.org/10.1016/j.jbankfin.2006.10.009

Erel, I. (2005). The effect of bank mergers on loan prices: evidence from the U.S. Market Paper. MIT Sloan School of Management, 2005.

Francis, B., Iftekhar, H., \& Haizhi,W. (2008). Bank consolidation and new business formation. Journal of Banking and Finance, 32(8), 1598-1612. http://dx.doi.org/10.1016/j.jbankfin.2007.11.015

Marsch, K., Christian, S., \& Katrin, F. (2007). Banking consolidation and small business finance: Empirical evidence for Germany. Discussion Papers. Deutsche Bundesbank, No 09-2007.

Mercieca, S., Klaus, S., \& Simon, W. (2009). Bank market structure, competition, and SME financing relationships in European Regions. Journal of Financial Service Research, 36(2-3), 137-155. $\mathrm{http}: / / \mathrm{dx}$.doi.org/10.1007/s10693-009-0060-0

Montoriol-Garriga, J. (2008). Bank mergers and lending relationships. Working Paper Series. European Central Bank, No. 934.

Sapienza, P. (2002). The effects of banking mergers on loan contracts. The Journal of Finance, 57(1), 329-366. http://dx.doi.org/10.1111/1540-6261.00424

Ugwunta, Ani., \& Ugwuanyi, (2012). The Effect of Bank Consolidation on Bank Credit Reduction: Evidence from Selected Banks in Nigeria. International Journal of Business and Management Tomorrow, 2(3), 1-8.

Zardkoohi A., \& Kolari, J. (2001). The effect of bank mergers and acquisitions on the credit decision process in small business lending. Finance India, 19-141. 